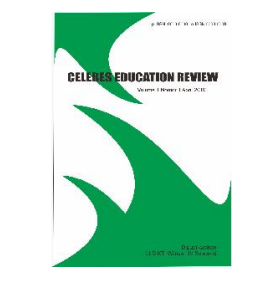

Celebes Education Review

http://journal.lldikti9.id/CER/index

Vol 1, No, 2, Oktober 2019

p-ISSN: 2656-7385 dan e-ISSN: 2684-7124

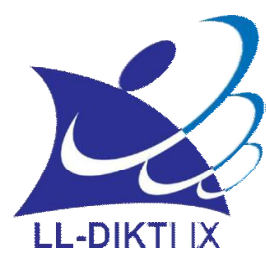

\title{
Analisis Semantik Terjemahan Alquran Surah Al Waqiah
}

\author{
${ }^{1}$ Andriani, ${ }^{2}$ Sulihin Azis \\ 1Bidang Ilmu Pendidikan Bahasa Indonesia, Universitas Al Asyariah Mandar \\ Email: andriani.ani2929@gmail.com \\ ${ }^{2}$ Bidang Ilmu Pendidikan Bahasa Indonesia, Universitas Al Asyariah Mandar
}

\section{Artikel info}

Artikel history:

Received; 25-07-2019

Revised:4-08-2019

Accepted;05-9-2019
Abstract. The meaning of the translation of the Qur'an in Islam has begun since the Qur'an itself was revealed. This tradition of meaning is one of the efforts that is expected to find the intrinsic meanings contained in the Qur'an which is the word of God. One such effort is with semantic analysis, an approach related to the meaning of the expression of a language. This study aims to describe the semantic analysis of the translation of the Qur'an Surah Al Waqiah verses 1-44 on the Al Mishbah interpretation. To achieve these objectives data on the meaning contained in the translation of the Qur'an Surah Al Waqiah verses 1-44 on the Al Mishbah interpretation by using note and document techniques. The results of the study obtained were Surah Al Waqiah discussing the Day of Resurrection, as the meaning of the word Al Waqiah is the Day of Resurrection. In surah Al Waqiah verses 1-44 explain about the events that occurred on the Day of Judgment that happened. Humans will be divided into three groups; the right, the left, and those who have been blessed first. Those who belong to the right and who get mercy beforehand will be placed in heaven and get invaluable pleasure, while those belonging to the left will be placed in hell and will be rewarded for their actions while living on earth.

Abstrak. Pemaknaan terhadap terjemahan Alquran dalam Islam sudah dimulai semenjak Alquran itu sendiri diturunkan. Tradisi pemaknaan ini salah satu upaya yang diharapkan akan menemukan makna-makna hakiki yang terdapat dalam Alquran yang merupakan kalam Allah. Salah satu upaya tersebut ialah dengan analisis semantik, pendekatan yang berhubungan dengan makna dari ungkapan suatu bahasa. Penelitian ini bertujuan untuk mendeskripsikan analisis semantik terjemahan Alquran Surah Al Waqiah ayat 1-44 pada Tafsir Al Mishbah. Untuk mencapai tujuan tersebut dikumpulkan data tentang makna yang terkandung dalam terjemahan Alquran Surah Al Waqiah ayat 1- 
44 pada Tafsir Al Mishbah dengan menggunakan teknik simak catat dan dokumen. Hasil penelitian yang diperoleh adalah surah Al Waqiah membahas mengenai hari kiamat, sebagaimana arti dari kata Al Waqiah yaitu hari kiamat. Dalam surah Al Waqiah ayat 1-44 menjelaskan tentang kejadian-kejadian yang terjadi pada saat hari kiamat itu terjadi. Manusia akan dibagi menjadi tiga golongan; golongan kanan, kiri, dan orang-orang yang telah mandapat rahmat terlebih dahulu. Mereka yang termasuk dalam golongan kanan dan yang mendapat rahmat terlebih dahulu akan ditempatkan di surga dan mendapatkan kenikmatan yang tidak ternilai, sementara mereka yang termasuk golongan kiri akan ditempatkan di neraka dan akan mendapat balasan perbuatannya selama hidup di dunia.

Keywords:

Alquran; Surah Al

Waqiah;

Semantik;
Coresponden author:

Email: $\underline{x x x @ g m a i l . c o m}$

artikel dengan akses terbuka dibawah lisensi CC BY -4.0

\section{Pendahualuan}

Alquran merupakan kitab suci yang dijadikan ruang untuk mengetahui dan mencatat semua kejadian masa kini, masa lampau, maupun yang akan datang yang terjadi di masyarakat. Alquran tersebut bukanlah suatu uraian-uraian dan ungkapan kosong atau khayalan yang sifatnya sekadar menghibur pembaca tetapi melalui Alquran ini dapat membuat pembaca menjadi lebih arif dan bijaksana dalam bertindak dan berpikir. Salah satu isi Alquran yang memuat nilai kearifan manusia terkhusus tentang hari kiamat tertera dalam surat Al Waqiah.

Menurut sejarah Alquran ini memuat informasi yang perlu digali dan dianalisis agar dapat diketahui oleh generasi berikutnya terkhusus analisis semantik. Alquran sebagian tidak punya makna tersendiri di kalangan masyarakat jika sepenuhnya di maknai hanya satu pandang saja. Beberapa opini yang muncul sehingga muncul pulalah pemahaman yang berbeda penafsiran. Surah Al Waqiah yang terdapat dalam Alquran tersebut baik tentang sejarah maupun makna.

Seseorang memperoleh ilmu sesuai dengan disiplin ilmu yang diikutinya, juga dituntut untuk aktif serta berani mengemukakan pendapat. Bukan hanya menjadi pendengar yang pasif, melainkan seseorang juga dituntut untuk aktif dalam merespon makna, utamanya dalam menganalisis makna yang terkandung dalam Alquran surah Al Waqiah.

Beberapa referensi yang ada, baik secara tertulis (media cetak) maupun secara lisan, pada umumnya umat Islam memahami bahwa Surah Al Waqiah selain menjelaskan tentang hari kiamat juga dapat digunakan sebagi doa ampuh salah satunya dapat mendatangkan rezeki. Sebagai peneliti harus mampu menafsirkan maksud dan tujuan apa yang akan menjadi titik utama pada objek yang diteliti, salah satu yang menjadi bagian terpenting yaitu kajian, untuk dapat menemukan jawaban yang diinginkan.

Semantik adalah suatu disiplin ilmu yang mengkaji tentang makna secara spesifik yang terdapat pada suatu teks ataupun ujaran. Semantik merupakan cabang linguistik yang pada lingkup kajiannya masih mengkaji objek bahasa[2]. Hal tersebut difokuskan dalam mengkaji makna suatu teks, menganalisis, dan melacak makna secara gramatikal hingga akhirnya dengan ditemukan makna-makna yang dimaksud dan diperluas dengan menggunakan metodologi 
analisis bahasa yang relevan. Semantik adalah sejenis ontologi, satu ontologi yang konkret, hidup dan dinamik, bukan semacam ontologi sistematik statik yang dihasilkan oleh seorang ahli falsafah pada tingkat pemikiran yang abstrak ${ }^{[1]}$.

Semantik adalah ilmu tentang makna atau tentang arti, yaitu salah satu dari tataran analisis Bahasa (fonologi, gramatikal dan semantik)[4]. Selanjutnya dalam pengertian yang lebih luas, bahwa semantik merupakan ilmu yang berhubungan dengan fenomena makna. Ini berarti bahwa metode analisis semantik, mengkaji kosa kata yang membentuk makna dan konsep dalam semantik dengan hingga unit yang paling sentral[3]. Jadi, makna mengombinasikan unitunit makna kosa kata dari unit yang paling elementer sebuah kata bisa menjadi berbeda atau memiliki nuansa yang berbeda pula. Semantik adalah penelitian makna yang membahas tentang bagaimana permulaan adanya makna sesuatu [5].

Jenis-jenis makna terdiri dari enam kelompok, yaitu: (1) Makna leksikal, gramatikal dan kontekstual; (2). Makna referensial dan non referensial; (3). Makna denotative dan makna konotatif; (4). Makna konseptual dan makna Asosiatif; (5). Makna kata dan makna istilah; (6). Makna idiom dan peribahasa[5].

Hal tersebut lebih difokuskan dalam mengkaji makna suatu teks, dengan menganalisis, dan melacak makna secara gramatikal hingga akhirnya ditemukan makna-makna yang dimaksud dan diperluas dengan menggunakan metodologi analisis bahasa yang relevan.

Alquran dengan berbagai gaya bahasa, unsur linguistik, dan ciri retorik yang menghasilkan kesan yang hebat ${ }^{[8]}$. Alquran sangat mengagumkan. Memperoleh dan memahami maksud leksikal di dalam Alquran memerlukan usaha yang mendalam disebabkan wujudnya berbagai gaya bahasa dan komponen linguistik yang membawa kesan tertentu pada konteks dan frasa. Perkataan di dalam Alquran mewujudkan gambaran dan aspek khusus serta menjelaskan konsep dan hubungan antara makna[10].

Berdasarkan hal-hal yang telah dikemukakan, masalah yang dikaji dalam penelitian ini adalah analisis semantik terjemahan Alquran Surah Al Waqiah ayat 1-44. Penelitian ini bertujuan untuk memahami makna yang tersirat dalam surah Al Waqiah yang merupakan pedoman hidup bagi umat Islam yang berkontribusi terhadap kearifan ummat masa lampau, masa kini, dan masa yang akan datang.

\section{Metode}

Penelitian ini termasuk jenis penelitian deskriptif kualitatif yang mendeskripsikan makna yang tersirat dalam surah Al Waqiah ayat 1-44. Instrumen penelitian dalam penelitian ini adalah peneliti sendiri atau human instrument yang berperan sebagai perencana, pelaksana, pengambil data, penganalisis, penafsir, dan sekaligus pelapor hasil penelitian dengan menggunakan teknik simak, catat, dan dokumen. Teknik Simak Catat simak dalam hal ini dilakukan menyimak dan memahami makna surah Al Waqiah ayat 1-44 pada Tafsir Al Mishbah, lalu mencatat makna-makna yang terkandung dalam setiap ayat surah Al Waqiah dengan menggunakan korpus data.Dokumen dalam penelitian ini adalah surah Al Waqiah ayat 1-44 yang terdapat dalam Alquran.

Pengetahuan dan wawasan kebahasaan peneliti khususnya teori tentang analisis semantik terjemahan Alquran surah Al Waqiah ayat 1-44 menjadi kunci pokok dalam keberhasilan penelitian. Data dalam penelitian ini adalah makna yang terkandung dalam Alquran surah Al Waqiah ayat 1-44. Adapun sumber data dalam penelitian ini adalah surah $\mathrm{Al}$ Waqiah ayat 1-44 yang terdapat dalam tafsir Al-Misbah. Proses analisis data dimulai dengan menelaah seluruh ungkapan-ungkapan dalam surah $\mathrm{Al}$ Waqiah ayat 1-44, kemudian dideskripsikan secara sistematis untuk memberikan gambaran secara cermat mengenai permasalahan yang dibahas sesuai dengan rumusan masalah dan tujuan penelitian. 


\section{Hasil dan Pembahasan}

\section{Hasil}

Ayat 1-6 menerangkan bahwa tidak seorang pun yang mampu mendustakan ketika hari kiamat datang, karena hal tersebut nyata dilihat langsung oleh setiap orang. Semasa di dunia banyak manusia yang mendustakannya karena belum melihat langsung kejadian tersebut dan belum merasakan langsung siksa atau balasan atas perbuatan yang telah dilakukan semasa hidup. Seseorang yang mendustakan hari kiamat akan merasakan azab yang sebenar-benarnya. Gempa yang menghancurkan semua isi bumi, gunung-gunung dan bangunan yang indah akan hancur lebur, sedangkan bagi yang meyakini adanya hari kiamat semasa hidup akan mendapat balasan yang setimpal dengan amal ibadah semasa hidup di dunia.

Ayat 7-14 menguraikan bahwa pada hari kiamat itupun manusia akan dibagi atas tiga golongan bergantung pada amal ibadah yang telah dilakukan. Pertama, golongan kanan yang adalah orang-orang yang menerima catatan amal perbuatan selama hidup dengan tangan kanan yang menandakan bahwa penghuni surga yang akan mendapat kebahagiaan. Kedua, golongan kiri adalah orang-orang yang menerima catatan amal perbuatan selama hidup dengan tangan kiri yang menandakan bahwa penghuni neraka yang akan mendapat azab yang sangat menyedihkan. Ketiga, memiliki kedudukan tertinggi adalah orang-orang yang terdahulu yang beriman yang telah mematuhi perintah-Nya, dan menerima rahmat dari Allah SWT, yang berbudi luhur dan telah dikagumi amal ibadah selama hidup. Mendahului siapapun yang masuk surga dan mendapatkan kenikmatan yang abadi. Golongan "As-sabiqunal-Muqarrabun" para sahabat Nabi dan ummat Nabi Muhammad SAW terdahulu yang pertama kali memeluk Islam.

Ayat 15-21 menggambarkan Kenikmatan yang didapatkan para ahli surga. Bersantai di atas dipan yang berlapis emas dan permata. Hidup dengan kabahagiaan dan kenikmatan yang tidak pernah didapatkan semasa hhidup di dunia. Dikelilingi para remaja yang menyenengkan ketika dipandang dan bertindak sebagai pelayan yang melayani para ahli surga diwaktu makan, minum, dan lain-lain. Ahli surga dilayani dengan dikelilingi oleh pelayan yang muda belia yang tidak dimakan usia dan selalu memenuhi semua yang dibutuhkan. Pelayan menyuguhkan aneka minuman (Khamr Surgawi) dengan mengambil langsung dari sumber mata air yang mengalir di surga dan tak ada habisnya yang tidak akan membuat mabuk. Selain minuman, makananpun disuguhkan kepada para ahli surga. Buah-buahan dan daging-daging disuguhkan bergantung dari diinginkan, bahkan cara memasak dari suguhan tersebut sesuai dengan keinginan dari para ahli surga.

Ayat 22-24 menjelaskan ayat-ayat yang lalu menyebut tempat, minuman, dan makanan bagi para penghuni surga, maka ayat ini tentang pendamping di surga. Ahli surga didampingi oleh bidadari-bidadari yang sangat cantik yang tidak tersentuh oleh apapun dengan mata indah yang cemerlang laksana mutiara. Kenikmatan yang telah didapatkan akan terasa sempurna ketika didampingi oleh bidadari-bidadari surga yang sangat cantik.

Ayat 25-26 mengungkapkan bahwa penghuni surga tidak akan mendengarkan perkataan dan sikap yang sia-sia ataupun perkataan dan sikap yang dapat menimbulkan dosa, melainkan akan mendengarkan kata-kata yang sopan dan baik, bertutur lembut, serta sikap sangat baik yang menyejukkan hati.

Ayat 27-40 menguraikan bahwa tentang kenikmatan yang didapatkan sekelompok yang paling tinggi derajatnya di sisi Allah SWT yakni golongan kanan yang paling utama. Kemudian, golongan kanan yang kedua adalah kelompok penghuni surga yang derajatnya lebih rendah daripada kelompok yang lalu, namun kesempurnaan dari kenikmatan yang didapatkan bukan berarti akan berkurang. Allah SWT berfirman: alangkah bahagianya golongan kanan kedua, tidak akan terbayangkan kenikmatan yang didapatkan oleh penghuni kelompok kedua, berada di antara pohon bidara yang tidak berduri, pohon kurma dengan buah yang bersusun-susun dengan keindahannya dan sangat menarik dipandang, naungan yang sangat luas di seluruh tempat dan sepanjang masa, air mengalir setiap kali diinginkan, buah-buahan yang manis dengan berbagai macam jenis ada disetiap diinginkan. Kemudian, pada ayat itu juga menyatakan 
bahwa telah diciptakan wanita-wanita surgawi yang akan menjadi teman maupun pasangan bagi penghuni surga dengan kesempurnaannya (gadis perawan, penuh cinta, umur sebaya, dan bentuk badan yang sangat indah). Wanita-wanita tersebut diciptakan untuk golongan kanan, baik yang termasuk golongan kanan yang utama atau sekelompok besar ummat terdahulu maupun golongan kanan generasi yang hidup setelah masa Nabi Muhammad SAW.

Ayat 41-43 menjelaskan keadaan golongan yang ketiga yakni penghuni neraka. Kelompok ketiga adalah golongan kiri atau golongan penghuni neraka. Golongan kiri berada dalam siksaan yang maha dahsyat, berupa angin angin yang sangat panas menembus pori-pori dan air panas yang mendidih, dan dalam naungan asap hitam yang berhembus dari neraka jahannam, sangat tidak sejuk dan tidak menyenangkan bila dihirup.

\section{Pembahasan}

Analisis makna terjemahan alquran surah Al Waqiah ayat 1-44 merupakan hal yang utama dalam penelitian ini. Makna konotatif yang terdapat pada terjemahan surah Al Waqiah ayat 1-44 yang dapat menimbulkan perbedaan persepsi. Hal ini berkaitan makna yang terkandung dalam setiap konteks kalimat yang disebut semantik.

Semantik adalah ilmu tentang makna atau tentang arti, yaitu salah satu dari tataran analisis Bahasa (fonologi, gramatikal dan semantik)[4]. Selanjutnya dalam pengertian yang lebih luas, bahwa semantik merupakan ilmu yang berhubungan dengan fenomena makna. Ini berarti bahwa metode analisis semantik, mengkaji kosa kata yang membentuk makna dan konsep dalam semantik dengan hingga unit yang paling sentral[3]. Jadi, makna mengombinasikan unitunit makna kosa kata dari unit yang paling elementer sebuah kata bisa menjadi berbeda atau memiliki nuansa yang berbeda pula. Semantik adalah penelitian makna yang membahas tentang bagaimana permulaan adanya makna sesuatu [5].

Penelitian ini menitikberatkan pada makna yang terkandung dalam surah Al Waqiah ayat 1-44 pada Tafsir Al Mishbah, bahwa hari kiamat adalah kejadian besar yang membuat seluruh isi dunia hancur berkeping-keping dan bertebaran di udara. Gunung-gunung, bangunan yang megah tidak akan ada lagi yang tersisa. Gempa bumi yang sangat dahsyat menghancurkan seluruh isi dunia. Orang-orang yang mendustakan akan adanya hari kiamat akan mendapat balasan dari perbuatan yang telah dilakukan, demikian halnya bagi yang telah meyakini akan hari kiamat akan mendapat balasan pula yakni kenikmatan surga.

Pada hari itu pula manusia akan dibagi dalam tiga golongan; Pertama, golongan kanan adalah orang-orang yang menerima catatan amal perbuatan selama hidup dengan tangan kanan yang menandakan bahwa penghuni surga yang akan mendapat kebahagiaan. Kedua, golongan kiri adalah orang-orang yang menerima catatan amal perbuatan selama hidup dengan tangan kiri yang menandakan bahwa penghuni neraka yang akan mendapat azab yang sangat menyedihkan. Ketiga, memiliki kedudukan tertinggi adalah orang-orang yang terdahulu yang beriman yang telah mematuhi perintah-Nya, dan menerima rahmat dari Allah SWT, berbudi luhur yang telah dikagumi amal perbuatan di dunia. Mendahului siapapun yang masuk surga dan mendapatkan kenikmatan yang abadi. Golongan "As-sabiqunal-Muqarrabun" para sahabat Nabi dan ummat Nabi Muhammad SAW terdahulu yang pertama kali memeluk Islam.

Kenikmatan yang didapatkan oleh para ahli surga. Bersantai di atas dipan yang berlapis emas dan permata. Hidup dengan kabahagiaan dan kenikmatan yang tidak pernah didapatkan semasa hhidup di dunia. Dikelilingi para remaja yang menyenengkan ketika dipandang dan bertindak sebagai pelayan yang melayani para ahli surga diwaktu makan, minum, dan lain-lain. Ahli surga dilayani dengan dikelilingi oleh pelayan yang muda belia yang tidak dimakan usia dan selalu memenuhi semua yang dibutuhkan. Pelayan menyuguhkan aneka minuman (Khamr Surgawi) dengan mengambil langsung dari sumber mata air yang mengalir di surga dan tak ada habisnya yang tidak akan membuat mabuk. Selain minuman, makananpun disuguhkan kepada para ahli surga. Buah-buahan dan daging-daging disuguhkan bergantung dari diinginkan, bahkan cara memasak dari suguhan tersebut sesuai dengan keinginan dari para ahli surga. 
Ahli surga didampingi oleh bidadari-bidadari yang sangat cantik yang tidak tersentuh oleh apapun dengan mata indah yang cemerlang laksana mutiara. Kenikmatan yang telah didapatkan akan terasa sempurna ketika didampingi oleh bidadari-bidadari surga yang sangat cantik. Penghuni surga juga tidak akan mendengarkan perkataan dan sikap yang sia-sia ataupun perkataan dan sikap yang dapat menimbulkan dosa, melainkan akan mendengarkan kata-kata yang sopan dan baik, bertutur lembut, serta sikap sangat baik yang menyejukkan hati.

Kenikmatan yang didapatkan sekelompok yang paling tinggi derajatnya di sisi Allah SWT yakni golongan kanan yang paling utama. Kemudian, golongan kanan yang kedua adalah kelompok penghuni surga yang derajatnya lebih rendah daripada kelompok yang lalu, namun kesempurnaan dari kenikmatan yang didapatkan bukan berarti akan berkurang. Allah SWT berfirman: alangkah bahagianya golongan kanan kedua, tidak akan terbayangkan kenikmatan yang didapatkan oleh penghuni kelompok kedua. Baik yang termasuk golongan kanan yang utama atau sekelompok besar ummat terdahulu maupun golongan kanan generasi yang hidup setelah masa Nabi Muhammad SAW semua akan mendapatkan kenikmatan surga yang sempurna. Kelompok ketiga adalah golongan kiri atau golongan penghuni neraka. Golongan kiri berada dalam siksaan yang maha dahsyat, berupa angin angin yang sangat panas menembus pori-pori dan air panas yang mendidih, dan dalam naungan asap hitam yang berhembus dari neraka jahannam, sangat tidak sejuk dan tidak menyenangkan bila dihirup.

\section{Simpulan dan Saran}

Kejadian-kejadian yang terjadi pada saat hari kiamat itu terjadi. Manusia akan dibagi menjadi tiga golongan; golongan kanan, kiri, dan orang-orang yang telah mandapat rahmat terlebih dahulu. Golongan kanan dan yang mendapat rahmat terlebih dahulu akan ditempatkan di surga dan mendapatkan kenikmatan yang tidak ternilai, sementara yang termasuk golongan kiri akan ditempatkan di neraka dan akan mendapat balasan perbuatan selama hidup di dunia. Ahli surga didampingi oleh bidadari-bidadari yang sangat cantik yang tidak tersentuh oleh apapun dengan mata indah yang cemerlang laksana mutiara. Kenikmatan yang telah didapatkan akan terasa sempurna ketika didampingi oleh bidadari-bidadari surga yang sangat cantik. Penghuni surga tidak akan mendengarkan perkataan dan sikap yang sia-sia ataupun perkataan dan sikap yang dapat menimbulkan dosa, melainkan akan mendengarkan kata-kata yang sopan dan baik, bertutur lembut, serta sikap sangat baik yang menyejukkan hati. Kenikmatan yang didapatkan sekelompok yang paling tinggi derajatnya di sisi Allah SWT yakni golongan kanan yang paling utama. Kemudian, golongan kanan yang kedua adalah kelompok penghuni surga yang derajatnya lebih rendah daripada kelompok yang lalu, namun kesempurnaan dari kenikmatan yang didapatkan bukan berarti akan berkurang. Allah SWT berfirman: alangkah bahagianya golongan kanan kedua, tidak akan terbayangkan kenikmatan yang didapatkan oleh penghuni kelompok kedua. Baik yang termasuk golongan kanan yang utama atau sekelompok besar ummat terdahulu maupun golongan kanan generasi yang hidup setelah masa Nabi Muhammad SAW semua akan mendapatkan kenikmatan surga yang sempurna. Kelompok ketiga adalah golongan kiri atau golongan penghuni neraka. Golongan kiri berada dalam siksaan yang maha dahsyat, berupa angin angin yang sangat panas menembus pori-pori dan air panas yang mendidih, dan dalam naungan asap hitam yang berhembus dari neraka jahannam, sangat tidak sejuk dan tidak menyenangkan bila dihirup.

Makna yang terdapat dalam terjemahan Alquran surah Al Waqiah hendaknya dapat dijadikan sebagai pedoman hidup setiap manusia, karena merujuk pada makna kata Al Waqiah itu sendiri adalah hari kiamat. Sebelum hari itu tiba sebagai manusia yang beriman sebaiknya mempersiapkan diri untuk bekal dikemudian hari, agar dapat terhindar dari golongan kiri dan menjadi makhluk yang termasuk pada golongan kanan yang mendapat kenikmatan dan keindahan surga yang sebenarnya. 


\section{Daftar Rujukan}

[1] Affandi, A., \& Su'ud, M. (2016). Antara Takwa Dan Takut (Kajian Semantik Leksikal Dan Historis Terhadap Al-Qur'an). Jurnal al Hikmah, 4(2), 111-123.

[2] Hanafi, W. (2017). Linguistik Al-Qur'an (Reinterpretasi Makna Manusia di Balik Surat alFatihah dalam Wacana Semantik). Studia Quranika: Jurnal Studi Quran, 2(1)

[3] Ismail, E (2016). ANALISIS SEMANTIK PADA KATA AHZAB DAN DERIVASINYA DALAM AL-QURAN. Al-Bayan: Jurnal Studi Al-Qur'an dan Tafsir, 1(2), 139-148.

[4] Rodriguez, MA, \& Egenhofer, MJ (2015). Menentukan kesamaan semantik di antarakelas entitas dari ontologi yang berbeda. IEEE Trans. tentang Pengetahuan dan Data Teknik, 15 (2), 442-456.

[5] Maknuna, A.A. (2015). KONSEP PAKAIAN MENURUT AL-QUR'AN (Analisis Semantik Kata Libas, Siyab, dan Sarabil dalam Al-Qur'an Perspektif Toshihiko Izutsu) (Doctoral Dissertation, IAIN Tulungagung)

[6] Verhaar, J.W.M. 2013. Asas-asas Llinguistik Umum. Yogyakarta: UGM Gaja Mada University Press.

[7] Hakim, R. (2014). Pembentukan Karakter Peserta Didik Melalui Pendidikan Berbasis AlQuran. Jurnal Pendidikan Karakter, (2).

[8] Munif Zarirruddin Fikri Nordin, Sharifah Fazliyaton Shaik Ismail. (2014). Some Linguistic Difficulties in Translating the Holy Quran from Arabic into English. International Journal of Social Science and Humanity, Vol. 2, No. 6. Pg 588-590.

[9] Shihab, m Quraish. (2010). Tafsir Al Mishbah (Volume 13) Pesan, Kesan, dan Keserasian al-Qur'an. Jakarta: Lentera Hati.

[10] Shihab Al-Nasser, Rafid A. Khashan. (2015). The Collocation of Mubeen In The Holy Quran. Journal of the College of Arts. University of Basrah. No 45. Sibawaih, A. (1988). Al-Kitab. Cairo, Egypt: Al-Khanji Library. 